\title{
STRATEGI PROMOSI DAN WORD OF MOUTH DALAM UPAYA PENINGKATAN KEPUTUSAN PEMBELIAN PRODUK TENUN
}

\author{
Dewi Astuti ${ }^{1}$, Sri Ernawati ${ }^{2}$ \\ ${ }^{1}$ Sekolah Tinggi Ilmu Ekonomi (STIE) Bima, dewiastutii16.stiebima@gmail.com \\ ${ }^{2}$ Sekolah Tinggi Ilmu Ekonomi (STIE) Bima, sriernawati.stiebima@gmail.com

\begin{tabular}{ll|lll}
\hline Article history & \multicolumn{5}{l}{} \\
\hline Dikirim tanggal & $: 17 / 02 / 2020$ & Diterima tanggal & $:$ & $02 / 09 / 2020$ \\
Revisi pertama tanggal & $: 02 / 09 / 2020$ & Tersedia online tanggal & $:$ & $29 / 09 / 2020$ \\
\hline
\end{tabular}

\begin{abstract}
ABSTRAK
Penelitian ini bertujuan untuk mengetahui pengaruh strategi promosi dan WOM (Word of Mouth) terhadap keputusan pembelian produk tenun di Kota Bima. Jenis penelitian yang digunakan yaitu asosiatif, lokasi penelitian di Kota Bima. Populasi dalam penelitian ini adalah semua konsumen yang pernah membeli kain tenun khas Bima, sampel dalam penelitian ini berjumlah 96 orang dengan teknik purposive sampling. Instrumen penelitian menggunakan kuesioner dengan pengukuran skala likert Adapun jenis data yang digunakan dalam penelitian ini adalah data kuantitatif dengan sumber data penelitian yaitu data primer. Teknik pengumpulan data yaitu observasi, angket/koesioner dan studi pustaka. Analisis data menggunakan regresi linear berganda. Hasil penelitian menunjukan bahwa strategi promosi berpengaruh terhadap keputusan pembelian produk tenun, WOM (word of mouth) berpengaruh terhadap keputusan pembelian produk tenun dan WOM (word of mouth) variabel yang paling dominan berpengaruh terhadap keputusan pembelian produk tenun di Kota Bima.

Kata Kunci : Strategi Promosi, WOM (Word of Mouth), Keputusan Pembelian
\end{abstract}

\section{ABSTRACT}

This study aims to determine the effect of promotion strategies and WOM (word of mouth) on the purchasing decisions of woven products in Bima City. The type of research used is associative, research location in Bima City. The population in this study are all consumers who have bought a typical Bima woven fabric, the sample in this study amounted to 96 people with purposive sampling technique. The research instrument used a questionnaire with a Likert scale measurement. The type of data used in this study was quantitative data with research data sources, namely primary data. Data collection techniques are observation, questionnaire and literature study. Data analysis uses multiple linear regression. The results showed that the promotion strategy influences the purchase decision of woven products, WOM (word of mouth) influences the purchasing decision of woven products and WOM (word of mouth) more dominant influence the purchase decision of woven products in Bima City.

Key Word: Promotion Strategy, WOM (Word of Mouth), Purchasing Decisions 


\section{PENDAHULUAN}

\section{Latar Belakang}

Perilaku konsumen di zaman sekarang cenderung berubah-ubah. Tentunya hal ini juga tidak lepas dari kemajuan ekonomi di negara-negara Asia, yang memberi dampak pada peningkatan pendapatan individual, sehingga konsumen di zaman sekarang lebih berorientasi pada nilai suatu produk dari pada harganya. Konsumen rela untuk membelanjakan uang lebih dengan tujuan mendapatkan pelayanan yang baik, yang tentunya memberi nilai kepuasan kepada konsumen. Salah satu faktor yang dapat mempengaruhi Keputusan Pembelian Promosi dan Word of Mouth (WOM).

Strategi promosi merupakan salah satu variabel dalam bauran pemasaran yang sangat penting dilaksanakan oleh perusahaan dalam memasarkan produk. Strategi Promosi merupakan kegiatan yang ditujukan untuk memengaruhi konsumen agar mereka dapat menjadi kenal akan produk yang ditawarkan oleh perusahaan kepada mereka dan kemudian mereka menjadi senang lalu membeli produk tersebut. Mengingat tingkat persaingan terus meningkat, maka pihak perusahaan harus meningkatkan kinerja perusahaan salah satunya adalah kinerja pemasaran, untuk membangun hubungan jangka panjang dengan pelanggannya atau calon pelanggan lain. Promosi adalah salah satu unsur bauran pemasaran yang sangat strategis terhadap peningkatan volume penjualan (Andari \& Napu, 2016).

Terjadinya word of mouth memicu calon konsumen baru untuk melakukan pembelian dalam sebuah produk yang telah didengarnya dari orang lain. Ketika calon konsumen sudah mengetahui tentang produk yang telah ditawarkan melalui promosi maupun mendapatkan informasi dari mulut ke mulut, maka calon konsumen berhak melakukan pertimbangan sebelum mereka memutuskan sebuah keputusan dalam pembelian (Nugraha et al 2015). Word Of Mouth (WOM) memiliki peran yang sangat berpengaruh atau efektif dalam kelangsungan hidup suatu perusahaan. Karena Word Of Mouth dapat menyebar luas secara cepat dan dipercaya oleh para calon konsumen. Penyebaran Word Of Mouth tidak hanya dapat dilakukan dengan cara pemberian informasi melalui komunikasi mulut ke mulut, tetapi juga dapat di sebarluaskan melalui media sosial internet yang ada. Word Of Mouth (WOM) lebih dikatakan efektif dalam kegiatan pemasaran karenakegiatan Word Of Mouth (WOM) didasari pengalaman seseorang dalam mengkonsumsi suatu produk atau jasa suatu perusahaan. Puas dan tidak puasnya seorang konsumen sangat berpengaruh terhadap dampak Word Of Mouth (WOM) baik positif maupun negatif yang akan timbul, sehingga mempengaruhi perusahaan tersebut.( Joesyiana, 2018)

Sejumah permasalahan yang ada tentang produk tenun di Kota Bima perlu mendapatkan perhatian lebih baik dari pemerintah maupun konsumen sebagai sebuah kearifan tradisi lokal dan budaya Bima yang harus dilestarikan. Strategi promosi yang ada selama ini seperti promosi melalui media cetak dan media sosial masih kurang optimal, lalu promosi dengan pemasangan spanduk/baliho masih kurang tepat lokasi pemasangannya sehingga masyarakat tidak dapat melihatnya dan pada akhirnya masyarakat sangat sedikit sekali yang membeli produk tenun hal ini terlihat pada observasi awal oleh peneliti. Begitu juga dengan WOM (word of mouth) yang disampaikan dari mulut ke mulut belum maksimal karena konsumen masih kurang antusias untuk membicarakan produk tenun dan berbagai keunggulannya. Padahal produk tenun Bima sudah dilirik di skala nasional maupun dunia, terbukti dengan banyak perancang mode yang menggunakan bahan tenun Bima dalam pagelaran fashion show. 
Berdasarkan latar belakang masalah tersebut peneliti tertarik meneliti tentang Strategi Promosi dan WOM (Word Of Mouth) terhadap keputusan pembelian produk tenun di Kota Bima.

\section{Rumusan Masalah}

Berdasarkan latar belakang diatas maka Rumusan Masalah Dalam Penelitian Ini Adalah Sebagai Berikut :

1. Apakah terdapat pengaruh strategi promosi terhadap keputusan pembelian produk tenun di Kota Bima?

2. Apakah terdapat pengaruh wom (word of mouth) terhadap keputusan pembelian produk tenun di Kota Bima?

3. Apakah strategi promosi atau wom (word of mouth) yang lebih dominan berpengaruh terhadap keputusan pembelian produk tenun di Kota Bima?

\section{Tujuan Penelitian}

Mengacu pada rumusan masalah tersebut di atas, maka tujuan dalam penelitian ini adalah:

1. Untuk mengetahui pengaruh strategi promosi terhadap keputusan pembelian produk tenun di Kota Bima

2. Untuk mengetahui pengaruh wom (word of mouth) terhadap keputusan pembelian produk tenun di Kota Bima

3. Untuk mengetahui strategi promosi atau WOM (word of mouth) yang lebih dominan berpengaruh terhadap keputusan pembelian produk tenun di Kota Bima

\section{Strategi Promosi}

\section{TINJAUAN LITERATUR}

Strategi promosi adalah usaha yang dilakukan perusahaan untuk menciptakan kesadaran, memberitahukan, membujuk dan mempengaruhi konsumen untuk melakukan pembelian produk yang di tawarkan perusahaan. (Rangkuti, 2014:77) Promosi adalah salah satu unsur dalam bauran pemasaran perusahaan yang didayagunakan untuk memberitahukan, membujuk, dan mengingatkan tentang produk perusahaan. Promosi adalah aktivitas yang mengkomunikasikan keunggulan produk dan membujuk pelanggan untuk membeli produk itu. Menurut Kotler dan Keller (2016:272) indikator strategi promosi diantaranya (1) Frekuensi Promosi, (2) Kualitas Promosi,(3) Kuantitas Promosi,(4) Waktu Promosi,(5) Ketepatan atau kesesuaian sasaran promosi.

\section{WOM (Word Of Mouth)}

Word of mouth adalah komunikasi dari orang ke orang antar sumber pesan dan penerima pesan dengan cara tidak komersial mengenai suatu produk, pelayanan, atau merek (Kotler dan Keller, 2016:280). Word of mouth adalah pemasaran mulut ke mulut yang memicu konsumen untuk mendeskusikan, mempromosikan merekomendasikan, untuk menjual merek suatu produk kepada pelanggan potensial lainnya (Sumardy, dalam Ernawati et al, 2018). Menurut Sernovitz (2014:31) terdapat lima indikator Word of Mouth yaitu,(1)Talkers (Pembicara)(2) Topics( Topik),(3) Tools (Alat),(4) Talking Part (Partisipasi),(5) racking (Pengawasan).

\section{Keputusan Pembelian}

Keputusan pembelian adalah sesuatu yang berhubungan dengan rencana konsumen untuk membeli produk tertentu, serta berapa banyak unit produk yang dibutuhkan pada periode tertentu (Setiadi, 2008:415). Menurut Sumarni (2015:86) Keputusan Pembelian 
memiliki lima indikator yaitu, (1) Keputusan tentang jenis produk, (2) Keputusan tentang merek, (3) Keputusan tentang jumlah produk,(4) Keputusan tentang waktu pembelian, (5) Keputusan tentang cara pembayaran

\section{Hipotesis}

H1 : Strategi promosi berpengaruh terhadap keputusan pembelian produk tenun di Kota Bima.

H2 : WOM (word of mouth) berpengaruh terhadap keputusan pembelian produk tenun di Kota Bima.

H3 : Strategi promosi atau WOM (word of mouth) yang lebih dominan berpengaruh terhadap keputusan pembelian produk tenun di Kota Bima.

\section{METODE PENELITIAN}

\section{Jenis Penelitian}

Jenis penelitian yang digunakan dalam penelitian ini adalah jenis penelitian assosiatif. jenis penelitian ini digunakan untuk mengetahui pengaruh strategi promosi dan WOM (Word Of Mouth) terhadap keputusan pembelian produk tenun di Kota Bima.

\section{Lokasi Penelitian}

Penelitian ini dilakukan di Kota Bima karena pada saat ini UMKM tenun dari Kota Bima yang banyak memproduksi kain tenun khas Bima yang dipasarkan di Kabupaten Bima, Kabupaten Dompu dan beberapa wilayah lainnya.

\section{Metode Pengumpulan Data}

Metode pengumpulan data yang digunakan dalam penelitian ini adalah metode sampel survey. Menurut Nazir (2011:217), sampel survey adalah suatu prosedur yang mana hanya sebagian dari populasi saja yang diambil untuk menentukan sampel yang diharapkan dapat mewakili populasi secara keseluruhan guna memperoleh gambaran yang cukup representatif.

\section{Instrumen Penelitian}

Pengukuran varibel penelitian dalam penelitian ini, setiap variabel akan diukur dengan menggunakan skor yang mengacu pada penggunaan skala likert. Skala likert digunakan untuk mengukur sikap, pendapat, dan persepsi seseorang atau sekelompok orang tentang fenomena sosial (Sugiyono, 2009). Dalam memberikan pembobotan padamasing-masing variabel diberikan pilihan jawaban Sangat Setuju (SS) yang diberi skor 5, Setuju (S) yang diber skor 4, Netral (N) yang diberi skor 3, Tidak Setuju (TS) yang diberi skor 2, dan Sangat Tidak Setuju (STS) yang diberi skor 1.

\section{Populasi dan Sampel}

Populasi adalah wilayah generalisasi yang terdiri atas obyek dan subyek yang mempunyai kualitas dan karakteristik tertentu yang ditetapkan oleh peneliti untuk dipelajari dan kemudian ditarik kesimpulannya Sugiyono (2009). Populasi yang digunakan adalah seluruh masyarakat Kota Bima yang pernah membeli kain tenun dan jumlahnya tidak diketahui secara pasti (unknown population), oleh karena itu, jumlah sampel yang diambil adalah sebanyak 96 orang. Sedangkan Teknik pengambilan sampel yang digunakan adalah purposive sampling, yaitu pemilihan sampel berdasarkan pada 
karakteristik tertentu yang dianggap mempunyai sangkut pautnyadengan karakteristik populasi yang sudah diketahui sebelumnya yaitu sesuai dengan kriteria sampel penelitian.

\section{Teknik Pengumpulan Data}

Penelitian ini dilakukan dengan mengumpulkan data melalui penyebaran quesioner pada masyarakat Kota Bima yang pernah membeli dan menggunakan produk tenun Bima, observasi dan studi pustaka.

\section{Jenis Data} kuantitatif

Jenis data yang digunakan dalam penelitian ini adalah kuantitatif. Data adalah data yang berupa angka-angka yang dapat dihitung dan diukur, data kuantitatif ini

berasal dari jawaban angket yang diberi skor kemudian dihitung dengan alat analisis yang

digunakan.

\section{Sumber Data}

Sumber data yang digunakan dalam penelitian ini adalah data primer yaitu data yang berasal dari hasil qusioner yang dibagikan kepada responden.

\section{Pengukuran Data}

Pengukuran Varibel Penelitian Dalam penelitian ini, setiap variabel akan diukur dengan menggunakan skor yang mengacu pada penggunaan skala likert. Skala likert digunakan untuk mengukur sikap, pendapat, dan persepsi seseorang atau sekelompok orang tentang fenomena sosial (Sugiyono, 2011). Dalam memberikan pembobotan pada masing-masing variabel diberikan pilihan jawaban Sangat Setuju (SS) yang diberi skor 5 ,

Setuju (S) yang diber skor 4, Netral (N) yang diberi skor 3, Tidak Setuju (TS) yang diberi

skor 2, dan Sangat Tidak Setuju (STS) yang diberi skor 1.

\section{Pengujian Data}

\section{UjiValiditas}

Hasil penelitian yang valid bila terdapat kesamaan antara data yang terkumpul dengan data yang sesungguhnya terjadi pada objek yang diteliti. Instrumen yang valid berarti alat ukur yang digunakan untuk mendapatkan data itu valid. Valid berarti instrumen tersebut dapat digunakan untuk mengukur apa yang seharusnya diukur, (Sugiyono, 2011: 172).

\section{UjiReliabilitas}

Hasil penelitia yang realibel, bila terdapat kesamaan data dalam waktu yang berbeda. Instrumen yang realibel adalah instrumen yang bila digunakan beberapa kali untuk mengukur objek yang sama, akan menghasilkan data yang sama, (Sugiyono, 2011: 172). 


\section{AsumsiKlasik}

\section{Uji Normalitas}

melihat

Salah satu cara termudah untuk melihat normalitas residual adalah dengan normal probability plot yang membandingkan distribusi kumulatif dari distribusi normal.

(Ghozali 2011:112)

\section{Uji Multikolonieritas}

Uji multikolonieritas bertujuan untuk menguji apakah dalam model regresi ditemukan adanya korelasi antar variabel independen. Untuk menguji multikolonieritas dilakukan dengan melihat (1). Nilai tolerance (TOL) dan lawannya, (2) variance inflation

factor (VIF) (Ghozali 2011:91).

\section{Uji Heteroskedastisitas}

Pengujian heteroskedastisitas bertujuan untuk menguji apakah dalam model regresi terjadi ketidaksamaan variance dari residual satu pengamatan ke pengamatan yang lain. Model regresi yang baik adalah tidak terjadi heteroskedastisitas dan untuk mengetahui adanya heteroskedastisitas dengan menggunakan uji Glejser. Jika variabel independen tidak signifikan secara statistik dan tidak memengaruhi variabel dependen, maka ada indikasi tidak terjadi heteroskedastisitas.

\section{Uji Autokorelasi}

Hasil uji Autokorelasi bertujuan menguji apakah dalam model regensi linear ada kolerasi antara kesalahan pengganggu pada periode $t$ dengan kesalahan pengganggu pada

periode t-1 (sebelumnya). Jika terjadi korelasi, maka dinamakan ada problem autokolerasi. Autokolerasi muncul karena observasi yang berurutan sepanjang waktu satu

sama lainnya. Uji Autokorelasi yang digunakan adalah Uji Durbin-Watson (DW test). (Ghozali 2011:96), untuk melihat apakah terjadi adanya atau tidak adanaya autokolerasi bisa ditentukan dengan kriteria berikut ini:

Angka $1,65<\mathrm{DW}<2,35$, berarti tidak terjadi autokolerasi Angka 1,21 $<\mathrm{DW}<1,16 / 2,35<2,79$, berarti tidak dapat disimpulkan Angka DW $<1,21 / \mathrm{DW}<2,79$, berarti terjadi autokolerasi

\section{Analisa Data Regresi Linier Sederhana}

Metode analisis yang digunakan dalam penelitian ini adalah analisis regresi linier berganda. yaitu dimana penulis ingin mengetahui pengaruh strategi promosi dan WOM (Word of Mouth) secara bersama mempunyai pengaruh terhadap keputusan pembelian produk tenun di Kota Bima. Model persamaan regresi untuk dua prediktor

adalah sebagai berikut:

$$
\begin{aligned}
& \mathrm{Y}=\mathrm{a}+\mathrm{b}_{1} \mathrm{X}_{1}+\mathrm{b}_{2} \mathrm{X}_{2} \\
& \text { Dimana : } \\
& Y \quad=\text { Keputusan Pembelian } \\
& \mathrm{X}_{1} \quad=\text { Strategi Promosi }
\end{aligned}
$$


$\mathrm{X}_{2} \quad=$ WOM (Word of Mouth)

a $\quad=$ Konstanta

$\mathrm{b}_{1}, \mathrm{~b}_{2}=$ Koefisien regresi

\section{Koefisien Korelasi (R)}

Koefisien korelasi bertujuan untuk mengukur hubungan antara variabel bebas terhadap variabel tidak bebas, (Sugiyono, 2011: 286).

\section{Koefisien Determinasi (R2)}

Koefisien determinasi ini bertujuan untuk melihat besar kecilnya pengaruh variabel bebas terhadap variabel tidak bebas, (Sugiyono, 2011: 286).

\section{Uji Signifikansi (Uji-t)}

Uji t bertujuan untuk melihat apakah variabel strategi promosi dan WOM (Word of Mouth) secara parsial mempunyai pengaruh terhadap keputusan pembelian produk tenun di Kota Bima.

\section{Uji (Uji-f)}

Uji f bertujuan untuk melihat apakah variabel strategi promosi dan WOM (Word of Mouth) secara bersama mempunyai pengaruh terhadap keputusan pembelian produk tenun di Kota Bima.

\section{HASIL PENELITIAN DAN PEMBAHASAN}

\section{Hasil Penelitian Uji Validitas}

Tabel 1. Hasil Uji Validitas

\begin{tabular}{|c|l|l|l|l|}
\hline $\begin{array}{c}\text { Variabel } \\
\text { penelitian }\end{array}$ & \multicolumn{1}{|c|}{ Pernyataan } & \multicolumn{1}{c|}{ rhitung } & rtabel & Keterangan valid \\
\hline \multirow{4}{*}{ Strategi Promosi } & Item 1 & 0,759 & 0,300 & Valid \\
\cline { 2 - 5 } & Item 2 & 0,795 & 0,300 & Valid \\
\cline { 2 - 5 } & Item 3 & 0,748 & 0,300 & Valid \\
\cline { 2 - 5 } & Item 4 & 0,785 & 0,300 & Valid \\
\cline { 2 - 5 } & Item 5 & 0,719 & 0,300 & Valid \\
\hline \multirow{4}{*}{ WOM } & Item 1 & 0,671 & 0,300 & Valid \\
\cline { 2 - 5 } & Item 2 & 0,779 & 0,300 & Valid \\
\cline { 2 - 5 } & Item 3 & 0,742 & 0,300 & Valid \\
\cline { 2 - 5 } & Item 4 & 0,751 & 0,300 & Valid \\
\cline { 2 - 5 } & Item 5 & 0,721 & 0,300 & Valid \\
\hline \multirow{4}{*}{$\begin{array}{l}\text { Keputusan } \\
\text { pembelian }\end{array}$} & Item 1 & 0,722 & 0,300 & Valid \\
\cline { 2 - 5 } & Item 2 & 0,802 & 0,300 & Valid \\
\cline { 2 - 5 } & Item 3 & 0,797 & 0,300 & Valid \\
\cline { 2 - 5 } & Item 4 & 0,842 & 0,300 & Valid \\
\cline { 2 - 5 } & Item 5 & 0,790 & & \\
\hline
\end{tabular}

Sumber : data Primer Diolah, 2020

Berdasarkan tabel 1 di atas, hasil pengujian validitas variabel promos idan WOM(Word of Mouth) dan keputusan pembelian produk tenun di kota Bima dapat dikatakan valid pada Corrected item-total correlation $>0,300$. Hasil pengujian validitas ini menunjukkan bahwa pernyataan kuesioner dalam penelitian ini valid. 
Hasil pengujian penelitian menggunakan pengukuran ini dapat dikatakan reliabel pada Cronbach alpha $>0,600$. Hasil pengujian reliabilitas ini menunjukkan bahwa pernyataan quesioner dalam penelitian ini reliabel.

Tabel 2. Hasil Uji Reliabilitas

\begin{tabular}{|l|l|l|l|}
\hline \multicolumn{1}{|c|}{ Variabel penelitian } & Cronbach's alpha & \multicolumn{1}{c|}{ Batas normal } & Keterangan Reliabel \\
\hline Strategi Promosi & 0,818 & 0,6 & Reliabel \\
\hline WOM & 0,783 & 0,6 & Reliabel \\
\hline Keputusan Pembelian & 0,849 & 0,6 & Reliabel \\
\hline
\end{tabular}

Sumber : data Primer Diolah, 2020

\section{Uji Asumsi Klasik}

Berikut ini adalah Hasil uji normalitas pada data penelitian, sehingga ketika hasil uji ini terpenuhi maka baru analisis dapat dilanjutkan.

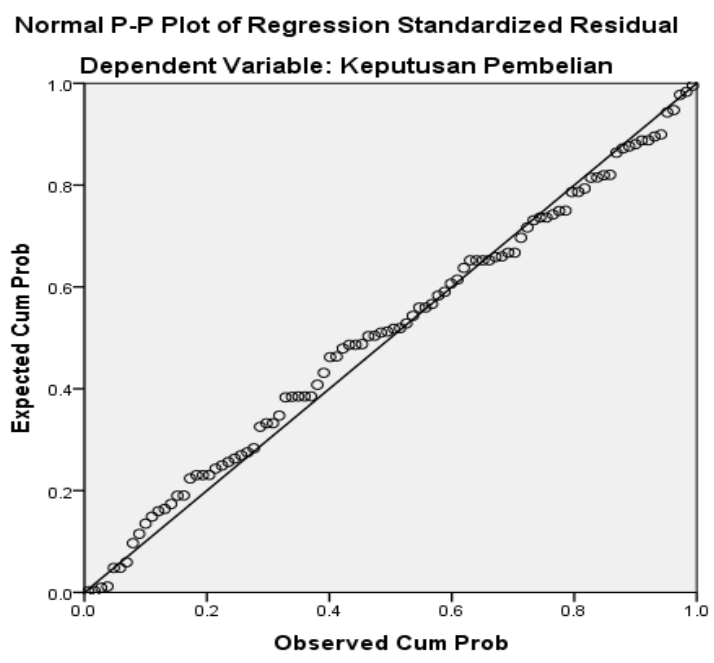

Gambar 1, Hasil Uji Normalitas

\section{Sumber : Data Primer Diolah}

Dari gambar tersebut dapat dilihat bahwa data penelitian memiliki penyebaran dan distribusi yang normal karena data memusat pada nilai rata-rata dan median atau nilai plot PP terletak digaris diagonal, maka dapat dikatakan bahwa data tersebut berdistribusi normal.

Untuk menegaskan hasil uji normalitas di atas, maka peneliti melakukan uji kolmogorov-smirnov dengan hasil sebagai berikut : 
Tabel 3. Hasil Uji Normalitas

One-Sample Kolmogorov-Smirnov Test

\begin{tabular}{|c|c|c|}
\hline & & $\begin{array}{l}\text { Unstandardiz } \\
\text { ed Residual }\end{array}$ \\
\hline \multirow[t]{2}{*}{$\mathrm{N}$} & & 96 \\
\hline & Mean & $0 \mathrm{E}-7$ \\
\hline Normal Parameters ${ }^{\mathrm{a}, \mathrm{b}}$ & $\begin{array}{l}\text { Std. } \\
\text { Deviation }\end{array}$ & 2.88847392 \\
\hline \multirow{3}{*}{$\begin{array}{l}\text { Most } \\
\text { Differences }\end{array}$} & Absolute & .066 \\
\hline & Positive & .046 \\
\hline & Negative & -.066 \\
\hline Kolmogorov-Smirnov Z & & .645 \\
\hline Asymp. Sig. (2-tailed) & & .799 \\
\hline
\end{tabular}

Sumber : Data Primer Diolah, 2020

Berdasarkan hasil uji kolmogorof-Smirnov di atas, terlihat nilai Asymp.Sig memiliki nilai $>0.05$. Hal ini menunjukkan bahwa data pada penelitian ini terdistribusi secara normal dan model regresi tersebut layak dipakai untuk memprediksi variabel dependen yaitu keputusan pembelian berdasarkan masukan variabel independen yaitu strategi promosi dan WOM (Word of Mouth). Maka data penelitian layak digunakan sebagai penelitian.

\section{Uji Multikolinearitas}

Uji ini mengindikasikan adanya hubungan yang kuat diantara variabel independen yang berarti ada kesamaan antara pengukuran variabel yang memberikan stimuli terhadap variabel dependen. Berikut ini adalah hasil pengujiannya.

Tabel 4. Hasil Uji Multikolinearitas

\begin{tabular}{llll}
\multicolumn{3}{c}{ Coefficients $^{\mathbf{a}}$} \\
\hline Model & & Tolerance & $\begin{array}{l}\text { Collinearity Statistics } \\
\text { VIF }\end{array}$ \\
\hline \multirow{2}{*}{1} & (Constant) & & \\
& Staregi Promosi & .426 & 2.348 \\
& WOM & .426 & 2.348 \\
\hline
\end{tabular}

a. Dependent Variable: Keputusan Pembelian

Sumber : Data Primer Diolah, 2020

Berdasarkan tabel 4 dapat diketahui bahwa setiap variabel memiliki nilai Tolerance tidak kurang dari 0.10 dan nilai Variance Inflation Faktor (VIF) tidak lebih dari 10. Analisis ini menunjukkan bahwa tidak terdapat gejala multikolinearitas terhadap variabel penelitian. Sehingga layak untuk digunakan dalam pengujian selanjutnya. Hal ini sesuai dengan Ghazali (2011 :95-96) dalam mendeteksi ada atau tidaknya multikolonieritas di dalam model regresi. 


\section{Uji Heteroskedastisitas}

Pengujian ini mengindikasi adanya ketidaksamaan variansi antara data-data yang diobservasi dalam penelitian. Berikut ini hasilnya.

Tabel 5. Hasil Uji Heteroskedastisitas

\begin{tabular}{lll}
\hline Variabel & Sig. & Kesimpulan \\
\hline Strategi Promosi & 0,404 & Non heteroskedastisitas \\
WOM & 0,119 & Non heteroskedastisitas \\
\hline
\end{tabular}

Sumber : Data Primer Diolah, 2020

Tabel. 5 di atas menunjukkan bahwa semua variabel mempunyai nilai signifikansi lebih besar dari 0,05 sehingga dapat disimpulkan bahwa model regresi pada penelitian ini tidak terjadi heteroskedastisitas.

\section{Uji Autokorelasi}

Tabel 6. Hasil Uji Autokorelasi

Model Summary ${ }^{b}$

\begin{tabular}{|c|c|c|c|}
\hline \multirow[t]{2}{*}{ Model } & \multicolumn{2}{|c|}{ Change Statistics } & \multirow[t]{2}{*}{ Durbin-Watson } \\
\hline & $\mathrm{df} 2$ & Sig. F Change & \\
\hline 1 & $93^{\mathrm{a}}$ & .000 & 2.526 \\
\hline
\end{tabular}

a. Predictors: (Constant), WOM, Strategi Promosi

b. Dependent Variable: Keputusan Pembelian

Sumber : Data Primer Diolah, 2020

Hasil uji autokolerasi diatas menunjukkan nilai statistik Durbin Watson sebesar 2.526 maka disimpulkan bahwa tidak terjadi autokolerasi.

\section{Regresi Linear Berganda}

Analisis regresi berganda dipilih untuk menganalisis pengajuan hipotesis dalam penelitian ini. Pengujian dilakukan dengan menggunakan program SPSS 20.00 forWindows.

Tabel 7. Hasil Uji Analisis Regresi Berganda

Coefficients $^{\mathbf{a}}$

\begin{tabular}{|c|c|c|c|c|c|}
\hline \multirow[t]{2}{*}{ Model } & \multicolumn{2}{|c|}{$\begin{array}{l}\text { Unstandardized } \\
\text { Coefficients }\end{array}$} & \multirow{2}{*}{$\begin{array}{l}\text { Standardized } \\
\text { Coefficients } \\
\text { Beta } \\
\end{array}$} & \multirow[t]{2}{*}{$\mathrm{t}$} & \multirow[t]{2}{*}{ Sig. } \\
\hline & B & Std. Error & & & \\
\hline (Constant) & 1.778 & 1.526 & & 1.165 & .247 \\
\hline Strategi Promosi & .294 & .108 & .291 & 2.710 & .008 \\
\hline WOM & .590 & .129 & .491 & 4.566 & .000 \\
\hline
\end{tabular}

a. Dependent Variable: Keputusan Pembelian

Sumber : Data Primer Diolah, 2020

Dari hasil analisis regresi dapat diketahui persamaan regresi berganda sebagaiberikut:

$\mathrm{Y}=1,778+0,294 \mathrm{X} 1+0,590 \mathrm{X} 2$ 
Berdasarkan persamaan tersebut, maka dapat dijelaskan sebagai berikut:

a. Nilai konstanta sebesar 1,778 dapat diartikan apabila variabel strategi promosi dan WOM (Word of Mouth) dianggap nol, maka keputusan pembelian akan sebesar 1,778 .

b. Nilai koefisien beta pada variabel promosi sebesar 0,294 artinya setiap perubahan variabel startegi promosi (X1) sebesar satu satuan maka akan mengakibatkan perubahan keputusan pembelian sebesar 0,294 satuan, dengan asumsi-asumsiyang lain adalah tetap. Peningkatan satu satuan pada variabel promosi akan meningkatkan keputusan pembelian sebesar 0,294 satuan.

c. Nilai koefisien beta pada variabel WOM (Word of Mouth) sebesar 0,590 artinya setiap perubahan variabel WOM (Word of Mouth) (X2) sebesar satu satuan, maka akan mengakibatkan perubahan keputusan pembelian sebesar 0,590 satuan, dengan asumsi-asumsi yang lain adalah tetap. Peningkatan satu satuan pada variabel WOM (Word of Mouth) akan meningkatkan keputusan pembelian sebesar 0,590 satuan.

\section{Uji Koefisien Determinasi}

Tabel 9. Hasil Uji Koefisien Determinasi

\begin{tabular}{|c|c|c|c|c|c|c|c|}
\hline \multicolumn{8}{|c|}{ Model Summary $^{\mathbf{b}}$} \\
\hline \multirow{2}{*}{$\begin{array}{l}\text { Model } \\
\text { Model }\end{array}$} & \multirow[t]{2}{*}{$\mathrm{R}$} & \multirow[t]{2}{*}{ R Square } & \multirow{2}{*}{$\begin{array}{l}\text { Adjusted } \\
\text { Square }\end{array}$} & \multirow{2}{*}{$\begin{array}{l}\mathrm{R} \text { Std. Error of the } \\
\text { Estimate }\end{array}$} & \multicolumn{3}{|l|}{ Change Statistics } \\
\hline & & & & & $\begin{array}{l}\text { R Square } \\
\text { Change }\end{array}$ & F Change & df1 \\
\hline 1 & $.736^{\mathrm{a}}$ & .542 & .533 & 2.91937 & .542 & 55.108 & 2 \\
\hline
\end{tabular}

a. Predictors: (Constant), WOM, Strategi Promosi

b. Dependent Variable: Keputusan Pembelian

Sumber : Data Primer Diolah, 2020

Hasil uji Adjusted $\mathrm{R}^{2}$ pada penelitian ini diperoleh nilai sebesar 0,533. Hal ini menunjukkan bahwa Minat Beli (Y) dipengaruhi oleh strategi promosi (X1) dan WOM (Word of Mouth) (X2) sebesar 54,2\%, sedangkan sisanya sebesar 45,8\% dipengaruhi oleh faktor lain yang tidak termasuk dalam penelitian ini.

\section{Hasil Uji Hipotesis}

Selanjutnya untuk mengetahui apakah hipotesis yang diajukan dalam penelitian ini diterima atau ditolak maka akan dilakukan pengujian hipotesis dengan menggunakan uji $t$ dan uji F. Hasil pengujian hipotesis dijelaskan sebagai berikut:

\section{Hasil Uji t}

Berikut ini hasil pengujian pengaruh antar variabel dalam penelitian.

Tabel 10. Hasil Uji t (Secara Parsial)

\begin{tabular}{|c|c|c|c|c|c|c|}
\hline \multirow{2}{*}{\multicolumn{2}{|c|}{ Model }} & \multicolumn{2}{|c|}{ Unstandardized Coefficients } & \multirow{2}{*}{$\begin{array}{l}\text { Standardized } \\
\text { Coefficients } \\
\text { Beta }\end{array}$} & \multirow[t]{2}{*}{$\mathrm{t}$} & \multirow[t]{2}{*}{ Sig. } \\
\hline & & $\mathrm{B}$ & Std. Error & & & \\
\hline \multirow{3}{*}{1} & (Constant) & 1.778 & 1.526 & & 1.165 & .247 \\
\hline & Strategi Promosi & .294 & .108 & .291 & 2.710 & .008 \\
\hline & WOM & .590 & .129 & .491 & 4.566 & .000 \\
\hline
\end{tabular}

a. Dependent Variable: Keputusan Pembelian

Sumber : Data Primer Diolah, 2020

H1 : Srategi promosi berpengaruh terhadap keputusan pembelian produk tenun di Kota Bima. 
Hasil statistik uji t untuk variabel promosi diperoleh nilai thitung sebesar 2,710 dengan nilai ttabel sebesar $1,985(2,710>1,985)$ dengan nilai signifikansi sebesar 0,00 lebih kecil dari $0,05(0,00<0,05)$, dan koefisien regresi mempunyai nilai positif sebesar 0,294; maka hipotesis yang menyatakan bahwa "promosi mempunyai pengaruh terhadap keputusan pembelian produk tenun di Kota Bima" terbukti. Hasil penelitian ini sama seperti hasil penelitian yang dilakukan oleh Permana, 2016 yang menyatakan bahwa variabel promosi memiliki pengaruh signifikan terhadap variabel keputusan pembelian konsumen PT. PIJI.

Promosi merupakan kegiatan dalam bidang pemasaran yang bertujuan untuk memberikan pengetahuan dan menginformasikan serta dapat mendorong permintaan terhadap produk, jasa dan ide dari perusahaan dengan cara mempengaruhi para pelanggan/ konsumen dengan sasaran agar mau membeli barang dan jasa yang dihasilkan oleh perusahaan. Jika suatu barang/jasa tidak dipromosikan atau tidak dikenalkan, maka produk yang dihasilkan oleh perusahaan tidak akan dikenal oleh masyarakat luas. Promosi berhubungan erat dengan Keputusan pembelian konsumen, karena apabila keputusan pembelian konsumen meningkat, maka secara tidak langsung pelanggan akan mempromosikan atau merekomendasikan produk tersebut kepada orang lain.

H2 : WOM (Word of Mouth) berpengaruh terhadap keputusan pembelian produk tenun di Kota Bima.

Hasil statistik uji t untuk variabel WOM (Word of Mouth) diperoleh nilai thitung sebesar 4,566 dengan nilai ttabel sebesar 1,985 $(4,566>1,985)$ dengan nilai signifikansi sebesar 0,00 lebih kecil dari $0,05(0,00<0,05)$, dan koefisien regresi mempunyai nilai positif sebesar 0,590; maka hipotesis yang menyatakan bahwa "WOM (Word of Mouth) mempunyai pengaruh terhadap keputusan pembelian produk tenun di Kota Bima" terbukti. Hasil penelitian ini sama seperti hasil penelitian yang dilakukan oleh Ernawati et al, 2018 yang menyatakan bahwa Word of Mouth (WOM) mempunyai pengaruh yang positif dan signifikan terhadap keputusan pembelian kain khas Daerah Propinsi Nusa Tenggara Barat (Study kasus pada kain Sasambo di Kota Bima).

Word of mouth (WOM) menjadi bagian penting dalam studi pemasaran mengingat bahwa komunikasi dalam Word of mouth (WOM) mampu mempengaruhi brand preference. Word of mouth (WOM) bertambah kuat mengingat bahwa manusia adalah makhluk sosial yang senang berinteraksi dan berbagi dengan sesamanya, termasuk masalah preferensi merek dalam hal pembelian. Word of mouth (WOM) mampu menyebar cepat bila individu yang menyebarkannya juga memiliki jaringan yang luas. Word of mouth (WOM) adalah suatu sarana komunikasi pemasaran yang efektif, murah, dan kredibel

H3 : Strategi promosi atau WOM (word of mouth) yang lebih dominan berpengaruh terhadap keputusan pembelian produk tenun di Kota Bima

Dari hasil pengujian diperoleh nilai thitung variabel Strategi Promosi sebesar 2,710 dengan nilai ttabel sebesar 1,985 (2,710>1,985 dan nilai variabel WOM (Word of Mouth) thitung sebesar 4,566 dengan nilai ttabel sebesar 1,985 (4,566>1,985. Dari data tersebut dapat dinyatakan bahwa WOM (Word of Mouth) merupakan variabel yang 
lebih dominan dominan berpengaruh terhadap keputusan pembelian produk tenun di Kota Bima

\section{Kesimpulan}

\section{KESIMPULAN DAN SARAN}

1. Strategi promosi mempunyai pengaruh terhadap keputusan pembelian produk tenun di Kota Bima, dimana Promosi penjualan merupakan unsur kunci dalam kampanye perusahaan dan promosi yang paling baik adalah promosi yan dilakukan oleh pelanggan yang puas

2. WOM (Word of Mouth) mempunyai pengaruh terhadap keputusan pembelian produk tenun di Kota Bima, dimana konsumen lebih mempercayai word of mouth communication (WOMC) dalam menilai sebuah produk, dan mempengaruhi keputusan pembelian mereka dibandingkan iklan. Cerita dan pengalaman seseorang menggunakan sebuah produk terdengar lebih menarik dan terpercaya yang bisa mempengaruhi pendengarnya untuk ikut mencoba produk tersebut

3. WOM (Word of Mouth) variabel yang lebih dominan berpengaruh terhadap keputusan pembelian produk tenun di Kota Bima, Sebagian besar proses komunikasi antar manusia dilakukan melalui word of mouth. Setiap hari seseorang berbicara dengan yang lainnya, saling bertukar pikiran, informasi, pendapat dan proses komunikasi lainnya. Pengetahuan konsumen tentang suatu produk lebih banyak dipengaruhi oleh word of mouth. Hal ini dikarekan informasi dari teman lebih dapat dipercaya dibandingkan dengan informasi yang didapatkan dari iklan

\section{Saran}

Saran yang bisa diberikan dari hasil penelitian ini seperti kita sebagai generasi penerus harus melestarikan kain tenun Bima yang merukana jati diri dari masyarakat Bima salah satu nya dengan tidak malu untuk menggunakan tenun Bima untuk busana forma maupun informal. Pemerintah Kota Bima harus berperan aktif dalam melestarikan warisan budaya agar keberadaan produk tenun bisa terus dikenal oleh generasi -generasi muda di Kota Bima dengan terus mempromosikan dan memperkenalkannya melalui pameran, festival budaya dan kegiatan kebudayaan lainnya, dan peneliti selanjutnya lebih mengangkat tema tentang stategi untuk melestarikan produk tenun di Kota Bima.

\section{REFERENSI}

Andari Rini \& Napu Maghfira Della, 2016. Pengaruh word of mouth terhadap keputusan pembelian tiket maskapai penerbangan domestik di davina tour and travel gorontalo. Tourism and Hospitality Essentials (THE) Journal, Vol.VI No.1.2016- 1013

Ernawati Sri, Muhajirin, Ismunandar. 2018 The effect of word mouth (wom) on purchasing decision of region exclusive fabric of west nusa tenggara profince (case study on sasombo fabric in bima city). Jurnal Terapan Manajemen Dan Bisnis Vol. 4 No 2 e-ISSN: 2477-5282 p-ISSN: 2599-3127 Page 115-119

Ghozali, Imam. 2011. Aplikasi Analisis Multivariate dengan program SPSS, Badan Penerbit Universitas Diponegoro, Semarang.

Joesyiana Kiki, 2018. Pengaruh word of mouth terhadap keputusan pembelian konsumen pada media online shop shopee di pekanbaru (Survey pada Mahasiswa Semester VII Jurusan Pendidikan Akuntansi Fakultas Keguruan dan 
Ilmu Pendidikan Universitas Islam Riau). Jurnal Valuta Vol. 4 No 1, April 2018 ISSN : 2502-1419 71

Kotler, Philip dan Armstrong, Gary. (2015). "Marketting an introducing”. 15th edition. Pearson Prenctice Hall. New Jersey.

Kotler, Philip dan Keller, Kevin Lane. (2016). "Marketing Management, 15th Edition". Pearson Education Limited. New Jersey.

Nugraha, A.A., Finna, Suhardyono., \& Kusumawati, A. (2015). Pengaruh terhadap keputusan pembelian dan kepuasan konsumen (studi kasus pada konsumen kober mie setan jalan simpang soekarno-hatta no. 1-2 malang). Jurnal Administrasi Bisnis (JAB) Vol 22 No.1.

Paputungan Rizkia .P, Soegoto S.A \& Roring Ferdy, 2018. Pengaruh promosi dan word of mouth terhadap keputusan pembelian di oriflame manado the influence of promotion and word of mouth on purchasing decision In Manado Oriflame. Jurnal EMBA Vol.6 No.4 Hal. 3703 - 3712

Permana Indra Doni, 2017. 2017 Pengaruh promosi terhadap keputusan pembelian produk lantai kayu dan pintu PT.PIJI di Jawa Timur. PERFORMA: Jurnal Manajemen dan Start-Up Bisnis Volume 2, Nomor 1

Rangkuti, Freddy (2014). "Riset Pemasaran". Gramedia Pustaka Utama. Jakarta.

Setiadi. 2013. "Perilaku Konsumen (edisi revisi)”. Liberty. Yogyakarta.

Sugiyono. 2011. Metode Penelitian Kuantitatif, Kualitatif dan R\&D. Bandung: Afabeta

Sumarni (2014). “Dasar-dasar Pemasaran”. Salemba Empat. Jakarta. 